\title{
Nitrogen dynamics in a feedlot soil
}

\author{
N. Wyngaard ${ }^{1}$, C. Videla ${ }^{1 *}$, L. Picone ${ }^{1}$, E. Zamuner ${ }^{1}$, N. Maceira ${ }^{2}$
}

${ }^{1}$ Facultad de Ciencias Agrarias, Universidad Nacional de Mar del Plata. Ruta 226 Km 74.5 CC 276 (7620)

Balcarce. 2 EEA INTA Balcarce, Ruta $226 \mathrm{Km} 74.5$ CC 276. (7620) Balcarce. *Corresponding author: cvidela@balcarce.inta.gov.ar

\begin{abstract}
The feedlot system (FL) generates a high input of sewage causing imbalances in the cycling process of nitrogen $(\mathrm{N})$ as well as a potential negative impact on the environment. The objective of this study was to deepen into the dynamics of $\mathrm{N}$ in a FL's soil so as to provide tools to reduce its environmental impact. The study was conducted in a FL, located in Balcarce County (Buenos Aires, Argentina). Soil samples were taken between November 2006 and May 2007 in a control Pasture, in the FL-High (Upper Slope position) and FL-Low (Lower Slope position) of the FL, and in the runoff area (RA). Urease activity and concentrations of Ammonium-N, Nitrate-N and urea-N were evaluated in the soil up to $60 \mathrm{~cm}$ depth. Urea-N values were always low $\left(6 \mathrm{mg} \mathrm{kg}^{-1}\right)$, due to the high urease activity measured (438 $\mathrm{mg} \mathrm{kg}$ $\left.{ }^{1}\right)$. Ammonium-N concentration was highest in FL-Low, reaching a value of 65.5 $\mathrm{mg} \mathrm{kg}^{-1}$ at 40-60 $\mathrm{cm}$ soil depth. Nitrate-N concentration was highest in FL-High for all depths, with a maximum concentration of $97.4 \mathrm{mg} \mathrm{kg}^{-1}$ in the $0-10 \mathrm{~cm}$ layer; at 40-60 cm depth, Nitrate-N concentration in FL was $31.98 \mathrm{mg} \mathrm{kg}^{-1}$, higher than that in Pasture $\left(1.21 \mathrm{mg} \mathrm{kg}^{-1}\right)$. There were no differences in Nitrate-N concentration between Pasture and RA; hence, it can be inferred that there was no transport of nitrate by surface water flow from the FL to RA. However, the potential for groundwater contamination via nitrate, a mobile soil constituent, should be studied.
\end{abstract}

Keywords: feedlot system - mineral nitrogen - urea nitrogen - urease activity. 


\section{Introduction}

The cattle feedlots (FL) generally cause an imbalance of soil nutrients, particularly of nitrogen $(\mathrm{N})$, increasing the $\mathrm{N}$ concentration in soil surface, which may eventually lead to water, air and soil contamination (Ball et al., 1979; Núñez et al., 2007). The FL has become an extensively-used practice over the last years in the livestock farms of Argentina as a beef production alternative, existing, back in 2009, 1687 FL that contain 1703676 head of cattle (SENASA, 2009). Under these systems, with high stocking rate, the return of excretions and loads of nutrients per surface are excessive.

Feedlot animals excrete about 60 to $80 \%$ of consumed $\mathrm{N}$ in urine and 20 to $40 \%$ in faeces, depending on the diet (Bierman et al., 1999; Van Horn et al., 1996). Fecal $\mathrm{N}$ contains $50 \%$ of organic $\mathrm{N}$ and $50 \%$ of ammonium, whereas urine contains up to $97 \%$ as urea, which is easily converted to ammonium upon contact with urease, a ubiquitous enzyme present in soils (Mobley et al., 1995; Mobley and Hausinger, 1989). In addition, the hydrolysis of urea produces $\mathrm{OH}^{-}$, which temporarily raises $\mathrm{pH}$ (Whitehead, 1989; Sherlock and Goh, 1984). When the equilibrium reaction between ammonium and ammonia $\left(\mathrm{NH}_{3}\right)$ in soil solution promotes the $\mathrm{NH}_{3}$ production, it is likely $\mathrm{NH}_{3}$ to be lost to the atmosphere, increasing the risk of environmental impact through eutrophication of surface water and acid deposition (Sapek, 1996). The $\mathrm{NH}_{3}-\mathrm{N}$ volatilization is enhanced by high soil $\mathrm{pH}$ and temperature, elevated wind velocity and low relative atmospheric humidity (Van Horn et al, 1996). In soils with alkaline $\mathrm{pH}$ in the surface, $\mathrm{NH}_{3}-\mathrm{N}$ volatilization losses from cattle urine ranged between 34 and 50\% during the summer and only between 7 and $10 \%$ in winter because the higher temperature in the summer time accelerated the hydrolysis of urea and subsequently promoted the $\mathrm{NH}_{3}$ volatilization (Videla et al., 1994).
Urease is an extracellular enzyme which secretion is not induced by urea. Urease is very distributed in nature and it has been found in microorganisms, plants and animals (Tabatabai, 1982). In soil, urease can be degraded by proteases or be associated with humus which impedes its denaturation, and extend its lifetime (Zantua et al., 1977; Mulvaney and Bremner, 1981; O'Toole and Morgan, 1984). The urease activity in soil is affected by $\mathrm{pH}$, temperature and moisture, and it is directly linked to soil organic carbon content (SOC) (Reynolds et al., 1985). In Mollisols (Typic Natraquoll) under grassland vegetation, the values of urease activity ranged from 55 to $154 \mathrm{mg} \mathrm{N} \mathrm{kg}^{-1} \mathrm{~h}^{-1}$, and were highly related with $\mathrm{SOC}$, total $\mathrm{N}$, cation exchange capacity and soil pH (Ferrari, 1995).

After urea hydrolysis, the ammonium concentration increases (Haynes and William, 1993). Several studies conducted on FL systems have found that ammonium concentrations to be as high as 100 to $250 \mathrm{mg}$ $\mathrm{N} \mathrm{kg}^{-1}$ at $10 \mathrm{~cm}$ soil depth (Ball et al., 1979; Carran et al., 1982; Sherlock and Goh, 1985) and from 500 to $1000 \mathrm{mg} \mathrm{N} \mathrm{kg}^{-1}$ in the surface $2.5 \mathrm{~cm}$ (Vallis et al., 1985), which were higher than those normally found on grasslands with no intensive livestock production (Norris, 2000). Ammonium is not a very mobile constituent in soils because it participates in cation exchange, but upon exchange site saturation, $\mathrm{NH}_{4}-\mathrm{N}$ can then be leaching (Vaillant et al., 2009).

After the deposition of ammonium from excretions, it can be mineralized to nitrite by specialized microorganisms (Nitrosomonas) and then rapidly to nitrate by Nitrobacter, in aerobic conditions. Nitrate is a very mobile anion since it is repelled from soil colloids having negative charges and it therefore remains in soil solution where is subject, among other processes, to leaching (Vallis et al., 1985). The environmental impact of nitrate leaching has a negative 
effect on human health, not only because can pollute the groundwater needed for human consumption but can also deteriorate the quality of the aquatic environment. The nitrate-N losses through leaching depend on the content of nitrate- $\mathrm{N}$ in soil, which changes through the year in agreement with the stocking rate and weather conditions.

In a FL located on calcareous soil, concentrations ranging between 1.7 and $5.0 \mathrm{mg}$ nitrate- $\mathrm{N} \mathrm{kg}^{-1}$ and between 245 and $348 \mathrm{mg}$ ammonium- $\mathrm{N} \mathrm{kg}^{-1}$ were reported at $10 \mathrm{~cm}$ soil depth (García et al., 2006). These concentrations decreased to $0.1-2.6 \mathrm{mg}$ nitrate- $\mathrm{N}$ and $6-7 \mathrm{mg}$ ammonium- $\mathrm{N} \mathrm{kg}^{-1}$ at $60 \mathrm{~cm}$ soil depth. In a FL located on a typic argiudoll soil, nitrate- $\mathrm{N}$ concentration was $15-50 \mathrm{mg} \mathrm{kg}^{-1}$ and ammonium concentration was $40-60 \mathrm{mg} \mathrm{kg}^{-1}$ at $10 \mathrm{~cm}$ depth, whereas at $60 \mathrm{~cm}$ depth, these concentrations ranged between 10-20 mg kg-1 and 10-40 $\mathrm{mg} \mathrm{kg}^{-1}$, respectively (Andriulo et al., 2003).

The variability of mineral-N concentrations, as a result of the FL's presence, highlights the need to know in every situation how will be the distribution of mineral $\mathrm{N}$ from the excreta in the soil profile, so as to determine the possibility of contamination by this element and/or losses of $\mathrm{N}$ as $\mathrm{N}$-ammonia, particularly in soils with alkaline $\mathrm{pH}$.

At the time when the negative impact of the FL already affected the quality of the environment, it is very difficult to implement remedial strategies because these are highly -expensive and time-consuming. Then, a greater understanding in nutrient dynamics is needed in order to develop systems that sustain production and environmental quality.

The objective of this work was to evaluate, over the time and at different soil depths, the changes in inorganic $\mathrm{N}$ concentrations, urea content, urease activity in a FL, an adjacent pasture considered as control area and an area which received surface flows from the FL with the purpose of establishing whether the high concentration of these compounds promotes movement through the soil to deeper horizons or to adjacent areas by runoff.

\section{Materials and methods}

This research was conducted in an open-air feedlot with the soil surface compacted and located in the southeastern area of Buenos Aires Province, Argentina ( $\left.37^{\circ} 48^{\prime} \mathrm{S} ; 5^{\circ} 13^{\prime} \mathrm{W}\right)$. The soil was classified as a Chelforó Series, a fine, mixed, thermic Vertic Natraqualf, characterized by the presence of a surface horizon with loam texture (16.1\% clay, $20.3 \%$ silt and $63.6 \%$ sand), and clay loam to clay subsoil horizons with low permeability due to high $\mathrm{Na}$ concentration. Climate is humid-subhumid mesothermal and the average annual precipitation is $879 \mathrm{~mm}$ (period 1971 - 2007). Mean annual maximum and minimum temperature are 19.6 and $8.1^{\circ} \mathrm{C}$, respectively, with annual mean thermal amplitude of $12.8^{\circ} \mathrm{C}$.

The feedlot pen has a surface of 0.8 ha and can accommodate 404 animals considering a capacity of $20 \mathrm{~m}^{2}$ animal ${ }^{-1 .}$ The number of animals was different among the sampling months, being of 131 animal units in November ( $\mathrm{AU}=$ equivalent to a $450 \mathrm{~kg}$ cow live weight), $33 \mathrm{AU}$ in December, $85 \mathrm{AU}$ in February and $62 \mathrm{AU}$ in May, that means, the maximum capacity was never exceeded. Animals were fed with a mixed ration composed of maize grains, potato starch and occasionally fine wheat bran. They also received 250 $\mathrm{g}$ day $^{-1}$ of mineral supplement which contains $60 \%$ of non-protein $\mathrm{N}$, vitamins, minerals and antibiotics.

\section{Soil sampling}

Two areas were selected within the feedlot pen, area permanently occupied by animals (FL): in the upper (FL-High) and lower (FL-Low) slope positions of the feedlot $(0.6 \%$ slope $)$. Outside of the feedlot, on the 
lower side of the farm, there is a depression that collects the runoff water from feedlot and adjacent fields and this area was identified as runoff area (RA). An additional site evaluated was the pasture (Pasture) or reference area composed by grasses, with no animal occupancy.

Three composite soil samples were taken at depths of 0-10, 10-20, 20-40 to 40-60 cm from each area in order to determine mineral N and urea-N. Simultaneously, soil samples of 0-2.5 cm depth for analyzing urease activity and soil $\mathrm{pH}$ were collected.

\section{Soil analysis}

Fresh soil samples $(0-10,10-20,20-40$ and 40-60 cm) were extracted $1 \mathrm{~N} \mathrm{KCl}$ shaken for $1 \mathrm{~h}$ in a reciprocating shaker at $170 \mathrm{rpm}$, placed in plastic containers of $250 \mathrm{~mL}$, and then filtered through Whatman $\mathrm{N}^{\circ} 1$ filter paper. Inorganic $\mathrm{N}$ (ammonium and nitrite + nitrate) was determined in these extracts by steam distillation in the presence of $\mathrm{MgO}$ and Devarda's alloy (Bremner and Keeney, 1965), and N-Urea was determined by using the colorimetric technique of Mulvaney and Bremner (1979). On air-dried samples collected at $0-10 \mathrm{~cm}$ depth and sieved to pass through a $2 \mathrm{~mm}$ sieve, soil $\mathrm{pH}$ was determined in a soil:water suspension $(1: 2.5)$ using a potentiometer and organic carbon (OC) content by the wet combustion procedure (Walkley and Black, 1934).

In the air-dried 0-2.5 cm samples collected during the first sampling (November 2006), was determined urease activity (Tabatabai and Bremner, 1973), quantifying of $\mathrm{N}_{-} \mathrm{NH}_{4}^{+}$produced when soil is incubated with a solution of urea and toluene at $37{ }^{\circ} \mathrm{C}$ for $2 \mathrm{~h}$. Ammonium-N was quantified by steam distillation with MgO (Bremner and Keeney, 1965). During the assay, $\mathrm{pH}$ was not adjusted with buffer solutions in order to determine the maximum hydrolysis that can be produced by soil at actual $\mathrm{pH}$. Toluene was used as a bacteriostatic, to inhibit the secretion or release by bacterial cells lysis of the urease enzymes during incubation.

\section{Statistical Analysis of Results}

The effect of sampling areas (FL-High, FL-Low, Pasture and RA) on the quantified variables was analyzed separately for each sampling depth using a SAS/Mixed procedure with RML estimation method. The used model considers the fixed effect of sampling areas. The random effects were modeled through the correlations among repeated measurements over the time (sampling time) subject to sub-sampling site, and included the random effect of subsampling. The error term was evaluated with various variance and covariance matrices, selecting the array that had lower Akaike criterion for each variable (SAS, 1988). Mean comparisons were carried out by using the Tukey-Kramer test with an established level of significance of $5 \%$.

\section{Results and discussion}

Surface soil $\mathrm{pH}$ values (Table 1) differed according to the sampling month and the month*sampling area interaction $(p<0.05)$. Significant differences were only found in May $(p<0.05)$. During this period the $\mathrm{pH}$ value for RA (9.5) was greater than that in other areas ( 7.3 on average). It might be inferred that the high rainfall during the previous month (rained in April $230 \mathrm{~mm}$, almost three times the historical median (Figure 1) transported $\mathrm{CaCO}_{3}$ and urea originated from animal manure (Koopmans et al., 2007) by surface runoff from the FL's highest pens, causing this elevated $\mathrm{pH}$ value. In the fact, since RA is a low area, soil moisture content after a period of precipitations is very high generating a low redox potential. This situation promotes a rise in $\mathrm{pH}$ which might reach values 
of up to 10 units of $\mathrm{pH}$ if carbonates are present (DeLaune and Reddy, 2005). En general, it was observed that $\mathrm{pH}$ values in May (7.81) were higher compared with the other months (7.10, average of November, December and February). This behavior might be due to the lower temperatures recorded during this month (Figure 1) which would not have favored losses by $\mathrm{NH}_{3}$ volatilization (He et al., 1999) and, therefore, the rise in $\mathrm{pH}$ upon hydrolysis of urea from animals urine may have not been regulated by that loss.

Table 1. Soil $\mathrm{pH}$ values $(0-10 \mathrm{~cm})$ in different months and sites: control pasture (Pasture), runoff area (RA) and upper (FL-High) and lower (FL-Low) slope positions of a feedlot. Letters show significant differences $(p<0.05)$ among sites.

\begin{tabular}{lcccc}
\hline & \multicolumn{4}{c}{ Soil pH $\mathbf{( 1 : 2 , 5}$ soil:water $)$} \\
\cline { 2 - 5 } & November & December & February & May \\
\hline RA & $6.4 \mathrm{a}$ & $6.5 \mathrm{a}$ & $7.3 \mathrm{a}$ & $9.1 \mathrm{a}$ \\
Pasture & $6.6 \mathrm{a}$ & $7.2 \mathrm{a}$ & $7.1 \mathrm{a}$ & $7.2 \mathrm{~b}$ \\
FL-Low & $7.2 \mathrm{a}$ & $7.4 \mathrm{a}$ & $7.3 \mathrm{a}$ & $7.5 \mathrm{~b}$ \\
FL-High & $7.5 \mathrm{a}$ & $7.6 \mathrm{a}$ & $7.1 \mathrm{a}$ & $7.4 \mathrm{~b}$ \\
\hline
\end{tabular}

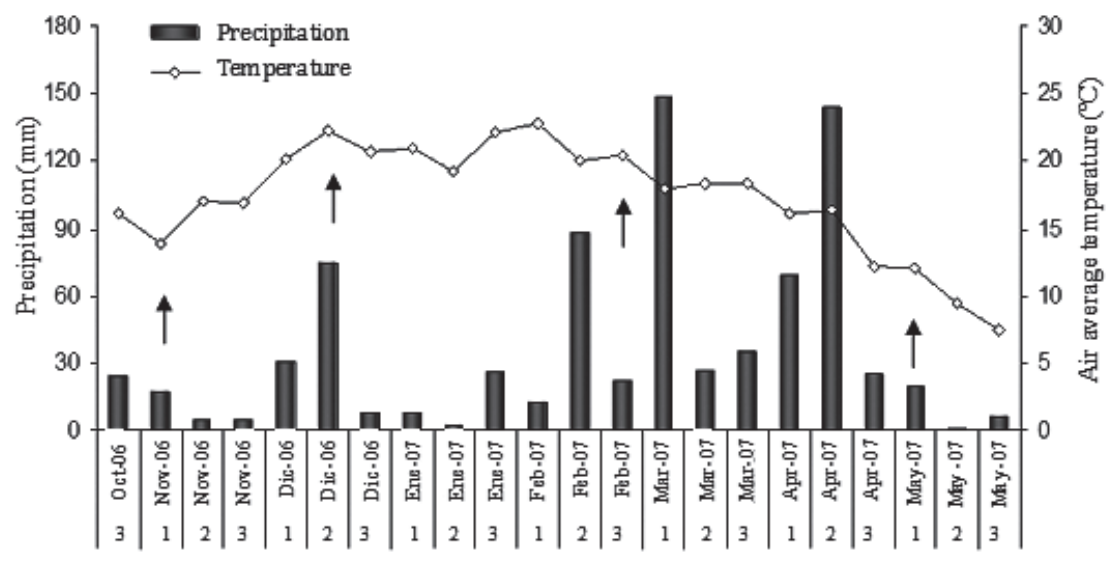

Time ( decades - months)

Figure 1. Mean air temperature and precipitations during experimental period at Balcarce-Argentina. Arrows indicate sampling times. 
Organic $\mathrm{C}$ levels at $10 \mathrm{~cm}$ depth showed variations among sampling months (Figure 2A) and areas (Figure $2 \mathrm{~B}$ ) but there was not significant interaction between months and areas. When the behavior of this variable was analyzed over months, it was observed a decrease in February but remained stable in the rest of the period. This situation might be due to the operation of decrust (elimination of the surface layer, which mainly contains manure mixed with surface soil), carried out in summer (Pordomingo, 2009), along with an increase in the oxidation rate of organic constituents, which normally takes place during the warm season. At the FL-Low, a greater amount of OC was quantified, which must have been due to a transfer of $\mathrm{C}$ from the highest areas of the feedlot pens through runoff of manure. The lowest $\mathrm{OC}$ value was registered in Pasture because it has no grazing animals and only received organic contributions from decomposition of vegetal tissues. The OC of RA showed intermediate values, since although not receiving animal excreta, it had higher water and nutrient accumulation, such as reactive $\mathrm{P}$ (Wyngaard et al., 2011) and mineral $\mathrm{N}$ (Figure 3), which might have favoured the development of plant biomass.
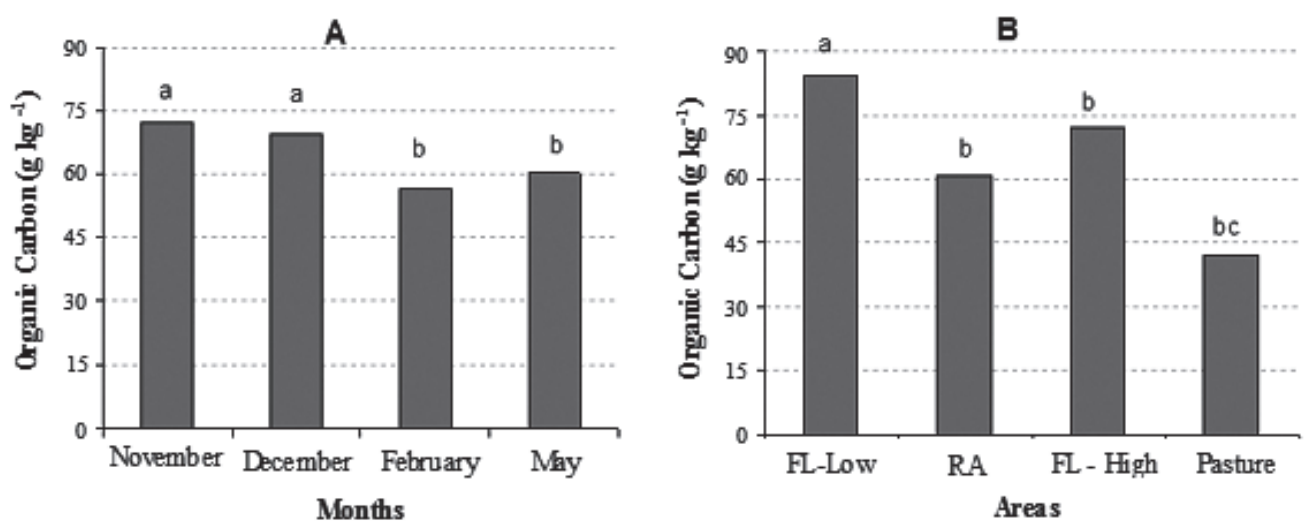

Figure 2. Soil organic carbon during (A) sampling months and (B) sampling areas, in a control Pasture (P), in the runoff area (RA) and in upper (FL-High) and lower (FL-Low) slope position of a feedlot system at BalcarceArgentina. Letters show significant differences $(p<0.05)$.

In spite of significant differences among sampling areas and months $(p<0.05)$, urea concentration in soil was always low, ranging between 3.5 and $6.0 \mathrm{mg} \mathrm{kg}^{-1}$ (Table 2), with the highest value registered in the FL and the lowest in the RA and Pasture. On the contrary, the urease activity was high, and the magnitude of this activity was in the order FL (FL-High= 441.3 $m g \mathrm{~kg}^{-1} \mathrm{~h}^{-1} \pm 27$, FL-Low $\left.=429.4 \mathrm{mg} \mathrm{kg}^{-1} \mathrm{~h}^{-1} \pm 17\right)>$ RA (140.7 mg kg-1 $\left.\mathrm{h}^{-1} \pm 28\right)$ y Pasture $\left(60.3 \mathrm{mg} \mathrm{kg}^{-1}\right.$ $\mathrm{h}^{-1} \pm 8$ ) (Table 2). This is the reason why the urea con- centration was very low, despite the great contribution of urea from the excreta the rate of urea decomposition was very high. This increase in urease activity at the FL compared with the Pasture was due to the presence of extra urease activity in the fresh faeces, showing average values of $2420 \mathrm{mg} \mathrm{N} \mathrm{kg}^{-1} \mathrm{~h}^{-1}$ at $30^{\circ}$ (Muck, 1982). The total decomposition of urea might occur within $6 \mathrm{~h}$ at $30^{\circ} \mathrm{C}$ or $24 \mathrm{~h}$ at $10^{\circ} \mathrm{C}$ when urease activity was very high (Muck, 1982), which justifies the low content of urea in systems having a high con- 
tribution of excretions, as it is the case of FL. Urease activity was significantly correlated with $\mathrm{CO}$ content ( $r=0.7265, p=0.0001)$, supporting the concept that the elevated contribution of organic constituents derived from excretions promotes the urease activity. Urease activity values obtained for the Pasture agree with those reported by Ferrari (1995) in soils from the same area, and they do not differ from those of the RA. This result suggest that there was not transfer of urea by runoff from the FL to the RA although the slope variation between both areas $\mathrm{N}$ mineral concentration (Figure 3 ) in soil showed fluctuations over sampling date and at sampling areas, with significant effects in all the sampled areas and moments at all the analyzed depths, as well as an interaction between both sources of variation $(p<0.05)$. Greater average values of ammonium-N were observed in FL-Low relative to Pasture. Though, due to the high variability found among the samples, the differences were only significant for 0-10 cm samples in February, 10-20 cm in November and December, and $20-40 \mathrm{~cm}$ in November and February. The highest concentration of urine depositions as a result of the location of the drinking troughs (Pordomingo, 2004) in the FLLow, justifies a higher ammonium average content as a consequence of the rapid hydrolysis of urea by the urease. In general, the conversion of ammonium to nitrate tends to rapidly take place in the soils of the region as a result of the elevated urease activity (Ferrari, 1995) and to the amount of nitrifying bacteria (Navarro et al., 1980) which prevents its accumulation; however in situations like those analyzed in this paper ammonia may accumulate. (Vaillant et al., 2009). This phenomenon was observed in this study, as elevated concentration of ammonium in FL relative to the control was detected at depth (Figure 3). Thus, although it was generally found that Ammonium-N decreased with depth, values of $78.6 \mathrm{mg} \mathrm{kg}^{-1}$ were determined in FL-Low at 20-40 $\mathrm{cm}$ depth in November (in comparison with 12.2 $\mathrm{mg} \mathrm{kg}^{-1}$ in Pasture) and of $37.9 \mathrm{mg} \mathrm{kg}^{-1}$ at $40-60 \mathrm{~cm}$ depth in December (in comparison with $0.9 \mathrm{mg} \mathrm{kg}^{-1}$ in Pasture). However, the differences were not statistically significant due to the high spatial variability, resulting from the erratic distribution of the animals' urine within the feedlot pen. The ammonium ion is a constituent that may adversely impact on the environment, either through surface runoff and/or by leaching, or as a greenhouse gas when volatilizing as ammonia (FAO, 2004).

Table 2. Urea-N concentration at different soil depths and surface urease activity in a control pasture (Pasture), in the runoff area (RA) and in upper (FL-High) and lower (FL-Low) slope positions of a feedlot system at Balcarce-Argentina.

\begin{tabular}{lcccc}
\hline & $\begin{array}{c}\text { Urea - N } \\
\left(\mathbf{m g ~ k g} \mathbf{~ k}^{-1}\right)\end{array}$ & $\begin{array}{c}\text { Urease activity } \\
\left(\mathbf{m g ~ k g}^{-1} \mathbf{h}^{-1}\right)\end{array}$ \\
\hline FL-High & $0-10 \mathrm{~cm}$ & $10-20 \mathrm{~cm}$ & $20-40 \mathrm{~cm}$ & \\
FL-Low & $5.10 \pm 0.51^{*}$ & $4.91 \pm 0,50$ & $4.64 \pm 0,26$ & $441.3 \pm 27,2$ \\
RA & $5.31 \pm 0.89$ & $4.96 \pm 0.92$ & $4.59 \pm 0.77$ & $429.4 \pm 16.9$ \\
Pasture & $4.78 \pm 0.56$ & $4.49 \pm 0.37$ & $4.58 \pm 0.60$ & $140.7 \pm 28.6$ \\
\hline
\end{tabular}

*average \pm standard deviation 

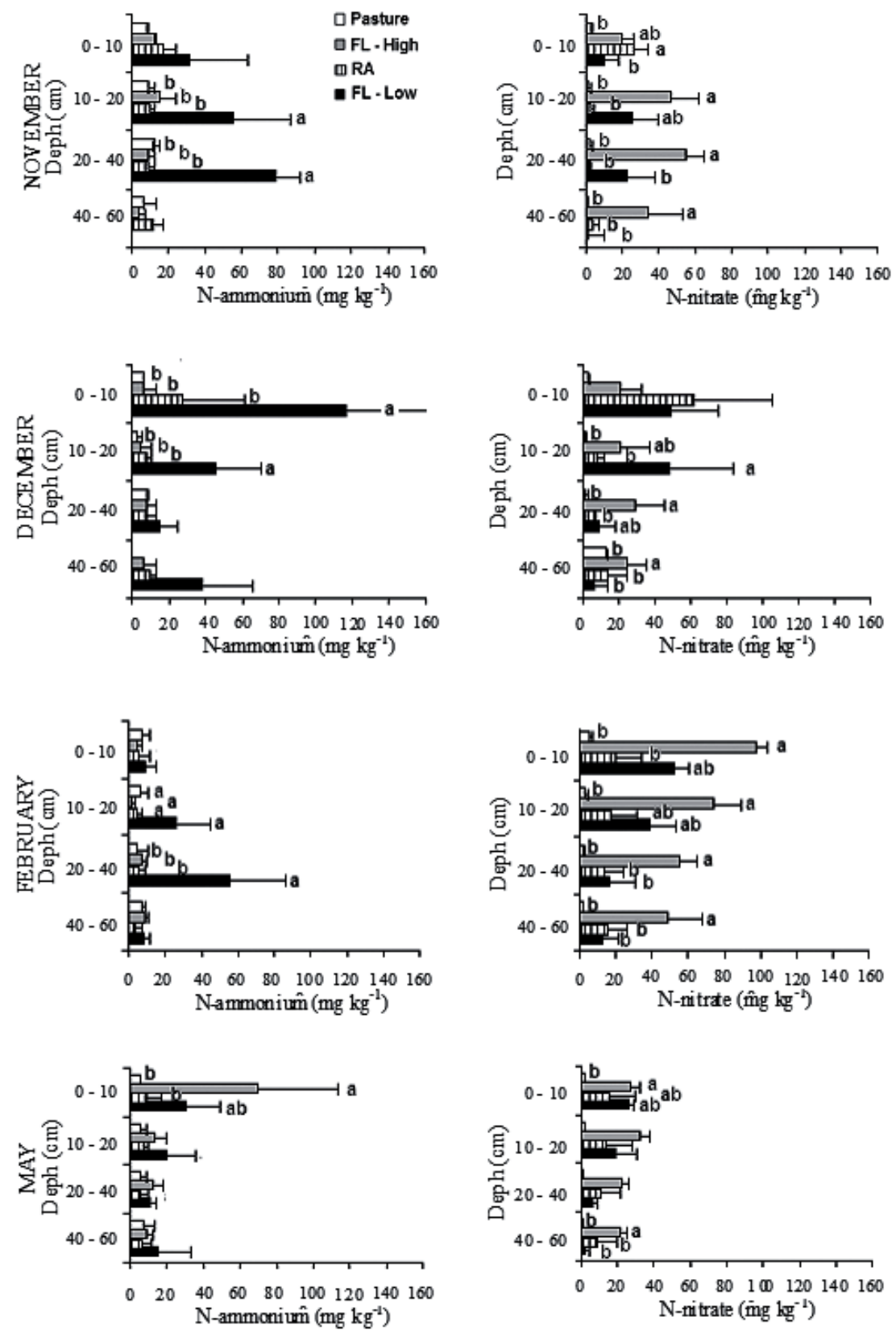

Figure 3. Soil Ammonium-N and nitrate-N contents in a control Pasture (P), in the runoff area (RA) and in upper (FL-High) and lower (FL-Low) slope position of a feedlot system at Balcarce-Argentina. Different letters show significant differences $(p<0.05)$ among sampling areas for each soil depth. 
The elevated concentration of ammonium coupled with high temperatures (Ferguson et al., 1984) promotes $\mathrm{N}$ losses by $\mathrm{NH}_{3}$ volatilization. Domingo et al., (2010) recorded cumulative $\mathrm{NH}_{3}$ losses of $60 \mathrm{~kg}$ $\mathrm{N}-\mathrm{NH}_{3}$ ha $^{-1}$ during a four-day period, in October and at the same FL, which means it is possible for the same process to have occurred at the FL-Low, mainly in February. Quantification and forecast of $\mathrm{NH}_{3}$ volatilization would turn out of major importance in FL systems since they are considered the greatest $\mathrm{NH}_{3}$ contributors to the atmosphere, causing enrichment of $\mathrm{N}$ in unwanted areas, an increase in acidity, and particle deposition (Steinfeld et al., 2006; Fen et al., 2003).

The nitrate concentration in soil (Figure 3) was consistently greater in FL-High at all depths and in most of the sampling dates, reaching maximum values of up to $97.4 \mathrm{mg} \mathrm{kg}^{-1}$ at $0-10 \mathrm{~cm}$ depth. For the same area, the average concentration of nitrate- $\mathrm{N}$ at 40 - $60 \mathrm{~cm}$ depth was $31.9 \mathrm{mg} \mathrm{kg}^{-1}$ (Figure 3), which was very high compared with the Pasture which at the same depth showed an average value of $1.2 \mathrm{mg}$ $\mathrm{kg}^{-1}$. These findings indicate that Nitrate-N can be transported by rainwater to greater depths than Ammonium-N, due to their lower susceptibility to being retained by exchange sites on surface horizons. When analyzing the average content of Nitrate-N in RA, was found to be comparatively higher than in Pasture only in the top $10 \mathrm{~cm}$, so it can be inferred that surface flow of Nitrate-N occurred from FL to RA.

The highest concentration of Nitrate-N was reached in February. This behavior is logical, considering the factors determining nitrification are substrate concentration $\left(\mathrm{NH}_{3}, \mathrm{CO}_{2} \mathrm{y} \mathrm{O}_{2}\right)$ temperature, moisture and soil $\mathrm{pH}$ (Stevenson Cole, 1999) and that, during February, a high stocking rate was combined at the FL (85 AU on average) alongside a maximum average temperature $\left(21^{\circ} \mathrm{C}\right)$, and there was also an increase in precipitations compared to the previous month (Figure 1). This behavior was even more pronounced in
FL-High (Figure 3). Furthermore, the lowest amount of animals in December as well as the low temperatures in May resulted in lower values of Nitrate-N being in soil during those months. At FL-Low there must surely have occurred, simultaneously to nitrification, $\mathrm{N}$ losses from $\mathrm{NH}_{3}$ volatilization. Although this process of loss was not quantified in this study, certainly the high concentrations of ammonium found (Figure 3), coupled with high temperatures (Figure 1) generated a marked difference in partial pressure of $\mathrm{NH}_{3}$ between soil and atmosphere encouraging the $\mathrm{NH}_{3}$ volatilization process (Ferguson et al., 1984).

The presence of Nitrate- $\mathrm{N}$ at a depth of 40-60 $\mathrm{cm}$ justifies the need of conducting a more thorough research study on nitrate leaching in feedlot systems since they constitute potential groundwater contaminants. Andriulo et al., (2003) found $40 \mathrm{mg} \mathrm{kg}^{-1}$ of nitrate in soil at $70 \mathrm{~cm}$ depth and groundwater contamination in two wells within a short distance from each other, although they concluded this would not necessarily imply the fact of the underlying aquiferous being contaminated.

\section{Conclusions}

The intensive beef-production system without control of sewage disposal of solid and liquid effluents eventually lead to significant modifications in soil $\mathrm{N}$ distribution, which varies over time according to weather conditions. The high rate of urease activity in feedlot pen soils prevents accumulation of urea, which led to low concentration of this constituent in all of the areas assessed. Notwithstanding, Nitrate-N and Ammonium-N content were always greater in feedlot pen soils than in control area, although they were highly-variable based on the position of the land, the distribution of animals within the pens and weather conditions. Nitrate-N concentration was higher in feedlot pens than in the control area, even at the 
maximum depths assessed, which highlights us about the need of further investigate the potential impact on groundwater. While no differences in concentration of ammonium $\mathrm{N}$ from the pasture and the area of control runoff, nitrate- $\mathrm{N}$ concentration in the first $10 \mathrm{~cm}$ of soil is higher in the runoff area due to surface transport process from the feedlot.

\section{Acknowledgements}

This research study has been conducted with funds from UNMdP AGR 240/07 and INTA PNECO 1302 projects.

\section{References}

Andriulo, A., C. Sasal, C. Améndola, F. Rimatori. 2003. Impacto de un sistema intensivo de producción de carne vacuna sobre algunas propiedades del suelo y del agua. RIA, 32: 27-56.

Ball, P.R., Keeney, D.R., Theobald, P.W., Nes, P. 1979. Nitrogen balance in urine-affected areas of a New Zealand pasture. Agron. J. 71:309-314.

Bierman, S., Erickson, G.E., Klopfenstein, T.J., Stock, R.A., Shain, D.H.1999. Evaluation of nitrogen and organic matter balance in the feedlot as affected by level and source of dietary fiber. J. Anim. Sci. 77:1645-1653.

Bremner, J.M., Keeney, D.R.. 1965. Steam distillation method for determination of ammonium, nitrate and nitrite. Anal. Chim. Acta 32:485-495.

Carran, R.A., Ball, P.R., Theobald, P.W., Collins, M.E.G. 1982. Soil nitrogen balances in urine-affected areas under two moisture regimes in Southland. N. Z. J. Exp. Agric. 10:377-381.

DeLaune, R.D., Reddy, K.R. 2005 Redox potential. In: Encyclopedia of Soils in the Environment. D. Hillel (ed). Academic Press. pp. 366-371.
Domingo, M. N., Picone, L.I., Videla, C., Zamuner, E., Maceira, N. 2010. Emisiones de amoníaco y dióxido de carbono en sistemas de engorde a corral. XXII Congreso Argentino de la Ciencia del Suelo. Rosario, Argentina. Resumen en Actas y trabajo completo de 4 páginas en CD ROM.

FAO. 2004. Estimaciones globales de las emisiones gaseosas de $\mathrm{NH}_{3}, \mathrm{NO}_{\text {y NO}}$ provenientes de tierras agrícolas. FAO e IFA Eds. 110 pp.

Fenn, M.E., Baron, J.S., Allen, E.B., Rueth, H.M., Nydick, K.R., Geiser, L., Bowman, W.D., Sickman, J. O., Meixner, T., Johnson, D.W. 2003. Ecological effects of nitrogen deposition in the western United States. BioScience. 53:404-420.

Ferguson, R.B., Kissel, D.E., Koelliker, J.K., Basel, A. 1984. Ammonia volatilization from surfaceapplied urea: Effect of hydrogen ion buffering capacity. Soil Sci. Soc. Am. J. 48:578-582.

Ferrari M.H. 1995. Hidrólisis de la urea en suelos de la región pampeana. Graduation thesis. FCAUNMdP, 36 pp.

García, A.R., Massobrio, M., Lo Valvo, P., Zamarro, D., Dorio, A.F. 2006. Dinámica de nutrientes en un suelo calcáreo utilizado como sostén en corrales de engorde. Proceedings of: XX Congreso Argentino de la Ciencia del Suelo. Salta, Argentina.

Haynes, R.J., Williams, P.H. 1993. Nutrient cycling and soil fertility in the grazed pasture ecosystem. Advances in Agronomy 49: 119-199.

He, Z.L., Alva, A.K., Carvet, D.V., Banks, D.J.. 1999. Ammonia volatilization from different fertilizer sources and effects of temperature and soil $\mathrm{pH}$. Soil Sci. 164: 750-758.

Koopmans, G.F., Chardon, W.J., McDowell, R.W. 2007. Phosphorus Movement and Speciation in a Sandy Soil Profile after Long-Term Animal Manure Applications. J. Environ. Qual. 36:305-315. 
Mobley, H.L.T., Island, M.D., Hausinger, R.P. 1995. Molecular biology of microbial ureases. Microbiol. Rev. 59:451-480.

Mobley, H.L.T., Hausinger, R.P. 1989. Microbial ureases: significance, regulation, and molecular characterization. Microbiol. Rev. 53:85-108.

Muck R.E. 1982. Urease activity in bovine feces. J Dairy science 65:2157-2163.

Mulvaney, R.L., Bremner, J.M. 1979. A modified diacetylmonoxime method for colorimetric determination of urea in soil extracts. Commun. Soil Sci. Plant Anal. 10: 109-112.

Mulvaney, R.L., Bremner, J.M. 1981. Control of urea transformations in soils. Soil Biochem. 5: 153-196.

Navarro, C.A., Echeverría, H.E., Gonzáles, N.S., Iglesias, M.A. 1980 Cinética de las reacciones de nitrificación y amonificación en los suelos del sudeste bonaerense. Proceedings of: Reunión Argentina de Ciencia del Suelo, 9. AACS, Paraná, Entre Ríos, Argentina.

Norris, M.D. 2000. Biogeochemical consequences of land cover change in Eastern Kansas. Kansas State University, Division of Biology. Thesis.

Núñez, P., Demanet, R., Matus, F., Mora, M.L. 2007. Grazing management, ammonia and nitrous Oxide emissions: a general view. J. Soil Sc. Plant Nutr. 7 (3) 2007: 61-99.

O’Toole P., Morgan, M.A. 1984. Termal stabilities of urease enzimes in some irish soils. Soil Biol. Biochem. 16: 471-474.

Pordomingo A.J. 2004. Engorde a corral. Available online at: http://produccionbovina.com/informaciontecnica/invernada_o_engorde_a_corral_o_ feedlot/78-feedlot.htm. (Acceced: October 2006)

Pordomingo, A.J. 2009. Gestión ambiental en el feedlot: Guía de buenas prácticas. Ediciones Instituto Nacional de Tecnología Agropecuaria. Publicación técnica, pp 95.
Reynolds C.M., Wolf, D.C., Armbruster, J.A. 1985. Factors related to urea hydrolysis in soils. Soil Sci. Soc. Am. J. 49: 104-108.

Sapek, A. 1996. Risk of water pollution as a result of agricultural activities. In sustainable agriculture and rural area development. Proceedings of Conference, Institute For Land Reclamation and Grassland Farming, Warsaw, pp. 79-99.

SAS Institute. 1988. User's Guide. Statistics. V.5. SAS. Cary. NC.

SENASA. 2009. Establecimientos de Engorde a Corral, Actualización 2007-2009. 10 p. Available online at: www.senasa.gov.ar/Archivos/File/ File1837-actfeedlot.pdf (Acceded: March 2011).

Sherlock R.R, Goh, K.M. 1985. Dynamics of ammonia volatilization from simulated urine patches and aqueous urea applied to pasture. 2. Theoretical derivation of a simplified model. Fertilizer Research 6: 3-22.

Steinfeld, H., Gerber, P., Wassenaar, T., Castel, V., Rosales, M., de Haan, C. 2006. Livestock's long shadow: Environmental issues and options. FAO, Rome.

Stevenson, F.J.; Cole, M.A. 1999. Cycles of soil. Carbon, nitrogen, phosphorus, sulfur, micronutrients. 2nd ed. John Wiley \& Sons, Inc., New York, EEUU. 427 p.

Tabatabai, M.A. 1982. Soil enzymes. In Methods of soil analysis. Part 2. Chemical and microbiological properties (A.L. Page et al., eds.) Agronomy 9. ASA y SSSA, Madison pp. 903-945.

Tabatabai, M.A., Bremner, J.M. 1973. Assay of urease activity in soils. Soil Biol. Biochem. 4:479-487.

USEPA (United States Environmental Protection Agency). 1995. Drinking water regulations and health advisories. p 11. Washington, DC. Office of water, US Environmental Protection Agency. 
Vaillant, G.C., Pierzynski, G.M., Ham, J.M., DeRouchey, J. 2009. Nutrient Accumulation below Cattle Feedlot Pens in Kansas. J. Environ. Qual. 38:909-918.

Vallis I., Peake, D.C.I., Jones, R.K., McCown, R.L. 1985. Fate of urea-N from cattle urine in a pasture crop sequence in a seasonally dry tropical environment. Aust. J. Agric. Res. 36:809-817.

Van Horn, H.H., Newton, G.L., Kunkle, W.E. 1996. Ruminant nutrition from an environmental perspective: Factors affecting whole-farm nutrient balance. J. Anim. Sci. 74:3082-3102.

Videla, C., Navarro C., González N., Miñón D. 1994. Volatilización de amoníaco a partir de orina de vacunos aplicada a suelos de la Pampa Deprimida. Ciencia del Suelo. 12:1-6.
Walkley, A., Black, T.A. 1934. An examination of the Degtjareff methods for determining of soil organic matter, and e proposed modification of the chromic acid titration method. Soil Sci. 37:29-38.

Whitehead, D.C., C.R. Lockyer, and N. Raistrick. 1989. Volatilization of ammonia from urea applied to soil: Infl uence of hippuric acid and other constituents of livestock urine. Soil Biol. Biochem. 21:803-808.

Wyngaard, N., Picone, L., Videla, C., Zamuner, E., Maceira, N. 2011. Impact of feedlot on soil phosphorus concentration. Journal of environmental protection. 2:280-286.

Zantua, M.I., Dumenil, L.C., Bremner, J.M. 1977. Relationships between soil urease activity and other soil properties. Soil Sci. Soc. Am. J. 41: 350-352. 